UDK 657.422:347.95(4-672EU)

https://doi.org/10.18485/union_pf_ccr.2021.ch16

Izv. prof. dr sc. Gabrijela Mihelčić ${ }^{*}$

\title{
ODABRANA PITANJA IZ PRAKSE SUDA EUROPSKE UNIJE O EUROPSKOM OVRŠNOM NASLOVU
}

\begin{abstract}
Apstrakt: Autorica promatra praksu Suda Europske unije o europskom ovršnom naslovu kao instrumentu naplate neosporenih novčanih tražbina. Analiza pokazuje važnost poštivanja načela uzajamnog povjerenja i uzajamnog priznavanja za potvrdu sudskih odluka, sudskih nagodbi te javnih isprava kao EON-a, jednako kao i za ovrhu na njihovu temelju. Posredno, omogućuje se pojačana zaštita potrošača, točnije, istraživanje potvrđuje da Sud slijedeći predmetna načela restriktivno tumači pretpostavke iz Uredbe (EZ) br. 805/2004 koje omogućuju slobodan protok sudskih odluka, sudskih nagodbi te javnih isprava u svim državama članicama imajući u vidu 'dobrobit' dužnika uopće.
\end{abstract}

Ključne riječi: načelo uzajamnog povjerenja, načelo uzajamnog priznavanja, Uredba (EZ) br. 805/2004, europski ovršni naslov.

\section{UVOD}

Vođen načelom uzajamnog povjerenja ${ }^{1}$ i u namjeri izostavljanja egzekvature ${ }^{2}$ europski zakonodavac predvidio je mogućnost naplate nespornih (neosporenih) novčanih tražbina posebnim sredstvom - europskim ovršnim naslovom (dalje u tekstu: EON) i uredio ga Uredbom (EZ) br. 805/2004 ${ }^{3}$ (dalje u tekstu: Uredba). ${ }^{4}$

* Sveučilište u Rijeci, Pravni fakultet, Katedra za građansko pravo, e-mail: gabrijela@pravri.hr

1 Marcos, M., 2013, European Union Civil Justice and European Union Criminal Justice, Waikato Law Review, Vol. 21, pp. 95-96, (http://www.austlii.edu.au/au/journals/WkoLawRw/2013/8.pdf, 23. 7. 2020).

2 Vid. Tampere European Council 15-16 October 1999. Presidency conclusions, (http://www.europarl.europa.eu/summits/tam_en.htm, 23. 7. 2020).

3 Regulation (EC) No 805/2004 of the European Parliament and of the Council of 21 April 2004 creating a European Enforcement Order for uncontested claims, OJ L 143, 30. 4. 2004, pp. 15-39, kod Babić, D., Jessel Holst, C., 2011, Međunarodno privatno pravo, Zagreb, Narodne novine, str. 794-833. Još, Kunštek, E., Pretpostavke za izdavanje potvrde o europskom ovršnom nalogu, 2007, Zbornik Pravnog fakulteta u Rijeci, Vol. 28, br. 1, str. 441-492.

4 Uredba je korigirana i izmijenjena u nekoliko navrata. Vid. Corrigendum to Regulation (EC) No 805/2004 of the European Parliament and of the Council of 21 April 2004 creating a European Enforcement Order for uncontested claims, OJ L 97, 15. 4. 2005, p. 64, (vid. članak 33. Uredbe). Vid. još, Commission Regulation (EC) No 1869/2005 of 16 November 2005 replacing the Annexes to Regulation (EC) No 805/2004 of the European Parliament and of the Council creating a European Enforcement Order for uncontested claims, OJ L 300, 17. 11. 2005, pp. 6-8, Regulation (EC) No 1103/2008 of the European Parliament and of the Council 
Uredba je izravno primjenjiv (članak 33(2) Uredbe) ${ }^{5}$ instrument prava Unije tzv. druge generacije 6 čija temeljna uloga jest omogućiti slobodan protok sudskih odluka, sudskih nagodbi i javnih isprava u svim državama članicama (članak 1. Uredbe). Odnosno, da se sudske odluke, sudske nagodbe i javne isprave potvrđene u jednoj državi članici (državi podrijetla) kao EON priznaju i izvrše (ovrše) u drugoj državi članici bez potrebe prethodnog priznavanja ili preispitivanja njihove ovršnosti (članak 5 . u vezi s čl. 24. i 25. Uredbe). U ovu se svrhu traže određene pretpostavke. Dijelom su te pretpostavke zajedničke i sudskim odlukama i sudskim nagodbama i javnim ispravama, a dijelom nisu. Primjerice, da bi se sudska odluka potvrdila kao EON i priznala i izvršila u drugoj državi članici, mora se u svojoj matičnoj državi donijeti u postupku provedenom prema tzv. minimalnim postupovnim standardima (iz čl. 12. do 19. Uredbe).

Sud Europske unije (dalje u tekstu: SEU) višekratno je tumačio Uredbu. Za materiju zaštite potrošača zanimljive su smjernice uz sudsku nadležnost za potrošače i sam pojam 'potrošača' kojima im je osiguran pojačan stupanj zaštite.

\section{ODNOS UREDBE I SRODNIH INSTRUMENATA PRAVA UNIJE}

Uredba ostvaruje čvrstu vezu s drugim instrumentima prava Unije, ${ }^{7}$ a posebice kada je riječ o njezinim 'domicilnim' uredbama - Uredbom (EU) br. $1215 / 2012^{8}$ (dalje u tekstu: Uredba1215/2012 ili Brussels I (recast)) koja je zamijenila staru Uredbu (EZ) br. 44/20019 (dalje u tekstu: Uredba 44/2001 ili Brussels

of 22 October 2008 adapting a number of instruments subject to the procedure laid down in Article 251 of the Treaty to Council Decision 1999/468/EC, with regard to the regulatory procedure with scrutiny - Adaptation to the regulatory procedure with scrutiny - Part Three, OJ L 304, 14. 11. 2008, pp. 80-84, Council Regulation (EC) No 4/2009 of 18 December 2008 on jurisdiction, applicable law, recognition and enforcement of decisions and cooperation in matters relating to maintenance obligations, $O J$ L 7, 10. 1. 2009, pp. 1-79.

5 Poretti, P., Pravo EU u građanskom procesnom pravu, u: Petrašević, T., Vuletić, I. (ur.), 2016, Procesno-pravni aspekti prava EU, Osijek, Pravni fakultet Sveučilišta Josipa Jurja Strossmayera u Osijeku, str. 106.

6 Hess, B., u: Hess, B. et al., 2008, The Brussels I Regulation 44/2001, The Heidelberg Report on the Application of Regulation Brussels I in 25 Member States (Study JLS/C4/2005/03), Munich, Verlag C.H. Beck, pp. 27-28 (http://ec.europa.eu/civiljustice/news/docs/study_application_brussels_1_en.pdf, 3. 5. 2019), Kačevska, I., Rudevska, B., General insight into the application of Regulations, u: Kačevska, I. (ur.) et al., 2012, Practical Application of European Union Regulations Relating to European Union Level Procedure in Civil Cases: the Experience in Baltic States, (https://www.just.ee, 3. 5. 2019), p. 6, Galič, A., 2016, Civil judicial cooperation, u: Handbook, English for Judicial Cooperation in Civil Matters, EJTN, (http://www.ejtn.eu/ Documents/Resources/Handbook_Manuel_Linguistics_Civil.pdf, 23. 7. 2020) pp. 16-20.

7 Kramer, X. et al., The application of Brussels I (Recast) in the legal practice of EU Member States, Synthesis Report, (https://www.asser.nl/media/5018/m-5797-ec-justice-the-application-of-brussels-1-09-outputs-synthesis-report.pdf, 23. 7. 2020) pp. 1-3.

8 Regulation (EU) No 1215/2012 of the European Parliament and of the Council of 12 December 2012 on jurisdiction and the recognition and enforcement of judgments in civil and commercial matters (recast), OJ L 351, 20. 12. 2012, pp. 1-32.

9 Regulation (EC) No 44/2001 of 22 December 2000 on jurisdiction and the recognition and enforcement of judgments in civil and commercial matters, OJ L 12, 16. 1. 2001, pp. 1-23. 
I), a na koju se zbog vremenskog pariteta Uredba izravno referira. Točnije, na nju se oslanja u velikoj mjeri, ${ }^{10}$ a vrijedi istaknuti i da se u članku 27 . Uredbe kaže da neće „utjecati na mogućnost traženja priznavanja i izvršenja sudske odluke, sudske nagodbe ili javne isprave o nespornim tražbinama temeljem Uredbe 44/2001.' 'Zamjena' Uredbe 44/2001 Uredbom 1215/2012 učinjena je tako što se „upute na prvu smatraju uputama na drugu“ (članak 80. Brussels I (recast)). U ovom kontekstu SEU naglašava da su njegova tumačenja o primjeni odredaba Brussels I i nadalje primjenjiva, radi li se o odredbama Brussels I (recast), „kad god se ta dva instrumenta prava Unije mogu smatrati istovjetnima “11 $\mathrm{pa}$, posljedično, i same Uredbe.

Uredba naglašava i vezu s Uredbom Vijeća (EZ) br. 1348/2000 ${ }^{12}$ (dalje u tekstu: Uredba 1348/2000), odnosno naglašava da neće utjecati na njezinu primjenu (članak 28. Uredbe). S tim što je i Uredba 1348/2000 'dobila' sljednicu - Uredbu (EZ) br. 1393/2007 ${ }^{13}$ (dalje u tekstu: Uredba 1393/2007), a ključ njihova međusobnog odnosa nalazi se u članku 25(2) Uredbe 1393/2007 koji kaže da se pozivanje na njezinu prethodnicu „smatraju pozivanjem na odredbe Uredbe 1393/2007“.

Pravila Uredbe o dostavi iz minimalnih postupovnih standarda posebne su naravi. ${ }^{14}$ Ta posebnost ne isključuje interakciju s pravilima Uredbe 1393/2007 koja se izvrsno vidi iz odluke koja će se infra citirati. U njoj je SEU detaljnije pojasnio članak 14(1) (a) Uredbe iako se, zapravo, bavio drugim pravilima ${ }^{15} \mathrm{i}$ kazao: „Kao što je to predviđeno člankom 14(1) (a) Uredbe, u odnosu na dostavu akta kojim se pokreće postupak u području nespornih tražbina, mogućnost da treća osoba preuzme sudsko pismeno umjesto njegova adresata može se primijeniti samo na odrasle osobe koje se nalaze unutar prostora u kojemu adresat boravi, bilo da se radi o članovima njegove obitelji koji žive na istoj adresi kao i on, bilo da se radi o osobama koje je on zaposlio na toj adresi. Logično je da će takve osobe stvarno predati predmetno pismeno njegovu adresatu. S druge strane, to nije neophodno slučaj kad je riječ o drugim trećim osobama, kao što je osoba koja živi u susjednom objektu ili osoba koja živi u istoj zgradi u kojoj adresat ima stan. Budući da preuzimanje pismena od strane treće osobe ne pruža dovoljna jamstva o tome da je adresat stvarno obaviješten u predviđenim roko-

10 U teoriji se govori o više razina povezanosti (čak četiri). Kačevska, I., Rudevska, B., Chapter 1: Latvia, Regulation 805/2004, pp. 138-139, članak 2. Uredbe, ili, izravna uputa na Brussels I iz članka 6. Uredbe.

11 CURIA, judgment of 15 November 2018, C-308/17, Hellenische Republik v. Leo Kuhn, para. 31, još, CURIA, judgment of 9 March 2017, C-551/15, Pula Parking d.o.o. v. Sven Klaus Tederahn, para. 31, CURIA, judgment of 16 November 2016, C-417/15, Wolfgang Schmidt v. Christiane Schmidt, para. 26.

12 Council regulation (EC) No 1348/2000 of 29 May 2000 on the service in the Member States of judicial and extrajudicial documents in civil or commercial matters, OJ L 160, 30. 6. 2000, pp. 37-52.

13 Regulation (EC) No 1393/2007 of the European Parliament and of the Council of 13 November 2007 on the service in the Member States of judicial and extrajudicial documents in civil or commercial matters (service of documents), and repealing Council Regulation (EC) No 1348/2000, OJ L 324, 10. 12. 2007, pp. 79-120.

14 Sessa, Đ., Katić, D. 2017, Dostava izvan Hrvatske, Zagreb, Pravosudna akademija, str. 28.

15 Mihelčić, G., 2019, O dostavi prema minimalnim standardima za potvrdu sudske odluke kao europskog ovršnog naslova, Pravo i porezi, 12, str. 68. 
vima, ono se za potrebe primjene Uredbe 1393/2007 ne može smatrati dovoljno pouzdanim. "16

\section{PRETPOSTAVKE ZA POTVRDU I IZVRŠENJE}

Uz pretpostavke koje se Uredbom traže za potvrdu i ovrhu na temelju sudskih odluka/sudskih nagodbi/javnih isprava ${ }^{17}$ SEU je postavljeno više pitanja. Kod polja primjene Uredbe, odnosila su se na pretpostavke za primjenu Uredbe ratione materiae i ratione temporis. S obzirom na zajedničke pretpostavke, problematiziran je koncept 'neosporene' tražbine. Od posebnih pretpostavki, kod sudskih odluka promatrano je udovoljavanje zahtjevima iz Uredbe i sudske odluke o troškovima, odgovoreno je na pitanje o određenju 'suda' u smislu Uredbe te zahtjevu da je odluka donesena od strane suda kao i na ona uz sudsku nadležnost i pojam potrošača povodom odluka o novčanim tražbinama čija se 'nespornost' procjenjuje prema posebnim kriterijima iz minimalnih postupovnih standarda. U ovom su svijetlu osobito naglašena uvodno navedena načela i njihova primjena kod pojedinih instituta (dostave, donošenja presude zbog ogluhe i sl.)

\subsection{PRETPOSTAVKE VEZANE UZ POLJE PRIMJENE UREDBE}

Da bi se ispunio zahtjev o primjeni Uredbe ratione materiae potrebno je da se u konkretnom slučaju radi o tzv. građanskoj ili trgovačkoj stvari (članak 2(1) Uredbe). Pojam građanske ili trgovačke stvari usko je vezan uz uređenje iz članka 1(1) Uredbe 44/2001, ${ }^{18} 19$ odnosno Uredbe 1215/2012 i predstavlja autonoman koncept. Definirajući pojam građanske ili trgovačke stvari u smislu Uredbe 1215/2012 (što je primjenjivo i na članak 2(1) Uredbe) SEU kaže da je „njegova ustaljena praksa zbog osiguranja što veće jednakosti i ujednačenosti prava i obveza koje proizlaze iz Uredbe 1215/2012 za države članice i zainteresirane osobe takva da se pojam 'građanske i trgovačke stvari' iz njezina članka 1(1) ne tumači kao jednostavno upućivanje na domaće pravo neke države članice [...] već da se smatra autonomnim pojmom i tumači oslanjajući se, $s$ jedne strane, na ciljeve i sustav Uredbe 1215/2012 i, s druge strane, na opća načela razvijena u svim nacionalnim pravnim sustavima." 20

16 CURIA, judgment of 2 March 2017, C-354/15, Andrew Marcus Henderson v. Novo Banco SA, paras. 95-97.

17 Vid. recital (7) Uredbe.

18 Hess, B., 2008, p. 29, Kačevska, I., Rudevska, B., 2012, pp. 19-28, Practice Guide for the Application of the Regulation on the European Enforcement Order, European Communities, 2008, (https://e-justice.europa.eu/fileDownload.do?id=2bfcfbd1-475b-4f60-94ec-05fc10d1d6e2, 23. 7. 2020) pp. 9-10.

19 CURIA, judgment of 22 October 2015, C-523/14, Aannemingsbedrijf Aertssen NV, Aertssen Terrassements SA v. VSB Machineverhuur BV, Van Sommeren Bestrating BV, Jos van Sommeren, para. 29, CURIA, judgment of 23 October 2014, C-302/13, flyLAL-Lithuanian Airlines v Starptautiskā lidosta Rìga VAS, Air Baltic Corporation AS, para. 24.

20 CURIA, judgment of 28 February 2019, C-579/17, BUAK Bauarbeiter-Urlaubs-u. Abfertigungskasse v. Gradbeništvo Korana d.o.o., para. 46, vid. i Pula Parking, para. 33. 
Što se tiče primjene Uredbe ratione temporis u pojedinim državama članicama $^{21}$ (čl. 26. i 33. Uredbe) ${ }^{22}$ ponovo odgovor dolazi iz sfere primjene srodnih pravila, ovaj put pravila o 'konceptu stupanja na snagu' prema članku 66. Uredbe 44/2001. SEU za njega kaže da treba biti shvaćen kao „datum od kada se Uredba 44/2001 primjenjuje u obje države članice, odnosno da se temeljem Uredbe 44/2001 presuda može priznati i izvršiti u slučaju da je u trenutku njezina donošenja Uredba 44/2001 bila na snazi i u državi članici podrijetla i u drugoj državi članici. “23

\subsection{PRETPOSTAVKE ZA POTVRDU SUDSKIH ODLUKA/SUDSKIH NAGODBI/JAVNIH ISPRAVA}

\subsubsection{Koncept 'neosporene' novčane tražbine}

Prema Uredbi, odluka/nagodba/isprava moraju se odnositi na novčanu tražbinu koja nije osporena, što predstavlja autonomni koncept ${ }^{24}$ (v. članak 4. drugu točku u vezi s člankom 3(1) Uredbe) ${ }^{25} \mathrm{U}$ pravu Unije koncepcija autonomnih pojmova najšire je prihvaćena (kako je vidljivo i iz supra navedenog primjera građanske i trgovačke stvari). Vrlo često, pozivajući se na svoju ustaljenu praksu, SEU naglašava da „iz zahtjeva za ujednačenu primjenu prava Unije kao i načela jednakosti proizlazi da se pojmovi iz odredbe prava Unije koja ne sadrži nikakvo izričito upućivanje na pravo država članica za utvrđivanje smisla i dosega u cijeloj Europskoj uniji trebaju tumačiti na autonoman i ujednačen način koji treba pažljivo izabrati uzimajući u obzir kontekst i cilj odredbe o kojoj se radi." ${ }^{26}$ Ovako je kazano i u predmetu u kojem je pažnja usmjerena na 'koncept neosporenosti' u svijetlu Uredbe i s obzirom na jednu posebnu vrstu odluka. Tako, „uvjeti prema kojima se $u$ slučaju donošenja presude $u$ odsutnosti ${ }^{27}$ tražbina smatra nespornom u smislu članka 3(1) drugog podstavka točke (b) Uredbe moraju biti utvrđeni na autonoman način na temelju te iste Uredbe." ${ }^{28}$ Zahtjev nespornosti toliko je važan da opredjeljuje i kriterije koji određuju primjenu Uredbe ratione materiae, pa SEU kaže (raspravljajući po prethodnom pitanju hrvatskog suda o

21 Kramberger Škerl, J., The Application "Ratione Temporis" of the Brussels I Regulation (Recast), u: Duić, D., Petrašević, T., (ur.) 2017, Procedural Aspects of EU Law, Osijek, Josip Juraj Strossmayer University of Osijek, Faculty of Law Osijek, p. 348. i d. (https://hrcak.srce.hr/ojs/ index.php/eclic/article/view/6536, 23. 7. 2020), Babić, D., Vremenske granice primjene uredaba 44/2001 i 1215/2012 u Hrvatskoj, u: Garašić, J. (ur.) 2013, Europsko građansko procesno pravo: izabrane teme, Zagreb, Narodne novine, str. 137. i d.

22 I uz pretpostavku da se Uredba primjenjuje prema teritorijalnom kriteriju (članak 2(3) Uredbe).

23 CURIA, judgment of 21 June 2012, C-514/10, Wolf Naturprodukte GmbH v. SEWAR spol. s r. o., paras. 33-34.

24 Kačevska, I., Rudevska, B., 2012, p. 46.

25 Vid. recital (5) Uredbe.

26 CURIA, judgment of 5 December 2013, C-508/12, Walter Vapenik v. Josef Thurner, para. 23.

27 Recital (6) Uredbe.

28 CURIA, judgment of 16 June 2016, C-511/14, Pebros Servizi v. Aston Martin Lagonda Ltd, para. 36. 
prigovoru na rješenje o ovrsi na temelju vjerodostojne isprave o kojima je odlučivao sud) „u ovom slučaju dotične dvije tražbine nisu nesporne u smislu članka 3. Uredbe jer su osporene pred navedenim sudom. Slijedom toga, Uredba nije primjenjiva ratione materiae." 29 Uredba razlikuje dvije vrste nesporenih novčanih tražbina: ${ }^{30}$ one iz članka 3(1) (a) i (d) te iz članka 3(1) (b) i (c). ${ }^{31}$

\subsubsection{Posebne pretpostavke za potvrdu sudskih odluka kao EON-a}

U prvoj točki članka 4. Uredbe propisano je da 'sudska odluka' znači „svaku sudsku odluku koju donosi sud države članice, bez obzira na njen naziv, uključujući dekret, nalog, odluku ili rješenje o izvršenju, te izračun troškova ili izdataka koje utvrđuje službenik suda." I ovaj se pojam autonomno koncipira, a za njegovo razumijevanje treba 'posegnuti' za člankom 32. Brussels I, odnosno odgovarajućom odredbom iz Brussels I (recast). ${ }^{32}$ Moguće je da se u toj ulozi pojavi i odluka o troškovima udovoljava li traženim pretpostavkama (v. članak 7. Uredbe), u prvom redu, odnosi li se na nespornu novčanu tražbinu (troškova). ${ }^{33}$ Stoga, kaže SEU, „članak 4. točku 1. i članak 7. Uredbe treba tumačiti na način da se ovršiva odluka o iznosu troškova povezanih sa sudskim postupkom sadržana u presudi koja se ne odnosi na nespornu tražbinu ne može potvrditi kao EON."34

Jedno od spornih pitanja bilo je ono o pojmu 'suda' u svjetlu članka 4. Uredbe, odnosno Uredbe uopće. ${ }^{35} \mathrm{SEU}$ je o njemu progovorio u jednom hrvatskom predmetu. ${ }^{36}$ U Hrvatskoj su javni bilježnici (isključivo) nadležni odlučivati o prijedlozima za ovrhu na temelju vjerodostojnih isprava i donositi rješenja po njima. Problem je nastao kada se javio upit o mogućnosti potvrde takvih bilježničkih rješenja kao EON-a. SEU nije prihvatio varijantu da ih se smatra 'sudskom odlukom', pa, čak, niti 'javnom ispravom. ${ }^{37}$ Istaknuo je da „zaštita načela legitimnih očekivanja u kontekstu slobodnog kretanja sudskih odluka [...] zahtijeva strogo ocjenjivanje elemenata koji definiraju pojam 'suda' u smislu Uredbe, kako bi se nacionalnim tijelima omogućilo identificiranje sudskih odluka koje su donijeli sudovi drugih država članica. Naime, poštovanje načela uzajamnog povjerenja u sudovanje u državama članicama Unije, na kojem se temelji primjena

29 CURIA, judgment of 7 May 2020, C-267/19 i C-323/19, PARKING d.o.o. and Interplastics s.r.o. v. SAWAL d.o.o. and Letifico d.o.o., para 49.

30 Torga, M., Chapter 3: Estonia, 2012, u: Kačevska, I. (ur.) et al., Practical Application of European Union Regulations Relating to European Union Level Procedure in Civil Cases: the Experience in Baltic States, (https://www.just.ee, 3. 5. 2019), p. 694.

31 Lazić, V., 2017, Regulations Brussels Ibis and Regulation creating a European Enforcement Order, (www.jacz.cz/images/stories/PROJECT_TRAINING_LEGAL_LANGUAGES/4_text_AJ/ Text4.pdf, 23. 7. 2020), pp. 37-38.

Kačevska, I., Rudevska, B., 2012, p. 34.

33 Ibid., p. 37.

34 CURIA, judgment of 14 December 2017, Case C-66/17, Grzegorz Chudaś, Irena Chudaśv. DA Deutsche Allgemeine Versicherung Aktiengesellschaft, para. 35.

35 Usp. da za razliku od nekih drugih pojmova, pojam „sud“ nije uređen Uredbom.

36 Vid. CURIA, judgment of 9 March 2017, C-484/15, Ibrica Zulfikarpašić v. Slaven Gajer, para. 43.

37 Vid. Opinion of Advocate General Bot delivered on 8 September 2016, para. 108. 
Uredbe, pretpostavlja, među ostalim, da su sudske odluke čije se izvršenje traži u državi članici različitoj od države podrijetla donesene u sudskom postupku koji nudi jamstva neovisnosti i nepristranosti kao i poštovanje načela kontradiktornosti postupka.” Zbog ovog i zaključak prema kojem „Uredbu treba tumačiti na način da javni bilježnici u Hrvatskoj, kada postupaju u okviru ovlasti koje su im povjerene nacionalnim pravom u ovršnim postupcima na temelju vjerodostojne isprave nisu obuhvaćeni pojmom 'suda' u smislu Uredbe" (Zulfikarpašić, § 50). ${ }^{38}$

Pretpostavke koje treba zadovoljiti sudska odluka da bi se potvrdila kao EON uređene su u članku 6. Uredbe. Prva je da je sudska odluka ovršna, a kada je ovršna određuje se u skladu s nacionalnim pravilima države članice podrijetla (članak 6(1)(a) Uredbe). ${ }^{39}$ Sudska odluka, zatim, treba biti donesena u postupku provedenom sukladno pravilima „,iz odjeljaka 3. i 6. II. poglavlja Uredbe $44 / 2001^{\text {“40 }}$ i time zahtjevi završavaju radi li se o tražbinama iz članka 3(1) (a) i (d) Uredbe. Međutim, kod tražbina iz članka 3(1) (b) i (c) Uredbe ${ }^{41}$ postoji još zahtjeva: oni koji se tiču sudske nadležnosti za potrošača - „prema članku 59. Uredbe 44/2001“42 te samog pojma 'potrošača., ${ }^{43}$ Odnosno, da je u postupku iz kojeg potječe sudska odluka bilo osigurano poštivanje minimalnih postupovnih standarda koje predviđaju članci 12. do 19. Uredbe. Vrijedi istaknuti i da je SEU, analizirajući članak 6. Uredbe, dao pojašnjenja vezana uz donošenje odluke o 'samom' potvrđivanju, a zaključak glasi „da odluku hoće li se sudska odluka potvrditi kao EON, a koja se može donijeti u bilo koje doba, može donijeti samo sudac." ${ }^{34}$

38 Vid. u ovom kontekstu C-267/19 i C-323/19. SEU objašnjava da je: „Sud u predmetima u kojima su donesene presude [...] Zulfikarpašić [...] i [...] Pula Parking [...] za potrebe donošenja odluke o tumačenju uredbi 805/2004 i 1215/2012 koje se od njega tražilo, analizirao hrvatski ovršni postupak na temelju vjerodostojne isprave koji javnim bilježnicima omogućuje odlučivanje o ovršnim prijedlozima podnesenima na temelju 'vjerodostojne isprave' donošenjem rješenja o ovrsi. Smatrao je da javnobilježničko razmatranje tih prijedloga ne ispunjava zahtjeve koji proizlaze iz načela kontradiktornosti te da javni bilježnici, kada postupaju u takvim ovršnim postupcima u okviru nadležnosti koje su im povjerene nacionalnim pravom, nisu obuhvaćeni pojmom 'sud' u smislu navedenih uredbi. Međutim, Sud je u tim predmetima samo analizirao pojam 'sud' u kontekstu zahtjeva koje nalažu Uredbe br. 805/2004 i 1215/2012 a da pritom nije ispitivao nadležnost javnih bilježnika u Hrvatskoj u ovršnim postupcima pokrenutima na temelju 'vjerodostojne isprave' koji nisu obuhvaćeni tim uredbama niti je pravio razliku između fizičkih i pravnih osoba“, CURIA, order of 6 November 2019, C-234/19, EOS Matrix d.o.o. v. Entazis d.o.o., para. 17.

39 Mizaras, V., Brazdeikis, A., Chapter 2: Lithuania, u: Kačevska, I. (ur.) et al., 2012, Practical Application of European Union Regulations Relating to European Union Level Procedure in Civil Cases: the Experience in Baltic States, (https://www.just.ee, 3. 5. 2019), pp. 445-446.

40 Ibid., p. 445. Vid. članak 6(1)(b) Uredbe.

41 Lazić, V., 2017, str. 37-38.

42 Vid. čl. 59-64 Brussels I i 62-65 Brussels I (recast).

43 Dapače, u predmetu Vapnenik apostrofirano je i da sam pojam 'potrošač' u smislu članka 6. stavka 1. točke (d) Uredbe „obuhvaća osobu koja sklapa ugovor za potrebe koje se mogu smatrati izvan opsega njegova poslovanja ili zanimanja s osobom koja se bavi svojim trgovačkim ili profesionalnim aktivnostima“ pa isti (članak) zato treba tumačiti na način „da se ne primjenjuje na ugovore sklopljene između dviju osoba koje nisu uključene u trgovačke ili profesionalne aktivnosti“, $\$ \$ 38-39$.

44 V. CURIA, judgment of 17 December 2015, C-300/14, Imtech Marine Belgium NV v. Radio Hellenic SA, para. 50, Vid. Opinion of Advocate General Villalón delivered on 8 September 2015, paras. 55-57, Mizaras, V., Brazdeikis, A., 2012, p. 444. 
Kako je već kazano, prema članku 12(1), pretpostavka za potvrdu sudske odluke o tražbini nespornoj u smislu članka 3(1)(b) i (c) Uredbe jest da je donesena u postupku u kojem su poštivani standardi iz čl. 12. do 19. Uredbe. ${ }^{45}$ Suštinu 'minimalnih postupovnih normi za nesporne tražbine' SEU je objasnio u više odluka i u njima se najbolje vidi uloga načela uzajamnog povjerenja i uzajamnog priznavanja. Najprije treba reći što uključuju minimalni standardi, a to je: „Te norme, koje služe za zaštitu prava obrane dužnika, ne uređuju samo načine dostave akta kojim se pokreće postupak i drugih akata već i sadržaj informacija takvog akta, s obzirom na to da dužnik mora biti obaviješten o tražbini kao i o postupku prema kojem je može osporiti“ (Pebros Servizi, $\$$ 8). Zatim, objasniti njihovu pravno-zaštitnu ulogu: „Minimalne norme [...] odražavaju volju zakonodavca Europske unije da se osigura da postupak koji dovodi do donošenja odluke o nespornoj tražbini nudi dovoljna jamstva poštovanja prava obrane $u$ državi članici podrijetla [...] uzimajući u obzir načelo nepostojanja provjere u tom pogledu u državi članici izvršenja. “46 Vice versa „u slučajevima donošenja presude zbog ogluhe u smislu članka 3 (1)(b) Uredbe upravo se kroz minimalne standarde osigurava postojanje dovoljnih jamstava za poštivanja prava obrane od kojih se ne može odstupiti“ (Pebros Servizi, $₫ 44) .{ }^{47}$

Jedno od pitanja koje se problematiziralo u okviru standarda ticalo se dostave. Uredba, naime, uređuje dostavu pismena kojima se pokreće postupak i drugih odgovarajućih pismena, ${ }^{48} \mathrm{i}$ to: dostavu dužniku s dokazom o primitku u članku 13; bez takvog dokaza u članku 14, te dostavu dužnikovu zastupniku u članku 15. Uredbe. Uređenje počiva na zahtjevu prema kojem „urednom dostavom nije moguće smatrati dostavu temeljenu na pravnoj fikciji o ispunjavanju minimalnih standarda. “49 Polazeći od svrhe 'uredne' dostave iz recitala (12) Uredbe i zahtjeva za poštivanjem temeljnih prava i načela, a osobito prava na pošteno suđenje,$^{50}$ imperativ je bio osigurati dužniku da bude obaviješten o postupanju suda protiv njega. Najveći stupanj takve sigurnosti postoji obavi li se dostava na neki od načina iz članka 13. Uredbe. Načine dostave koji su predviđeni u članku 14. Uredbe pružaju niži stupanj sigurnosti i podvrgnuti su strožoj kontroli (recital (14) Uredbe).

Pretpostavka za dostavu nekim od načina dostave iz članka 14. Uredbe jest da je adresa dužnika utvrđena sa sigurnošću i od tog nije moguće odstupiti (članak 14(2) Uredbe) ${ }^{51} \mathrm{pa}$, stoga, „obzirom na članak 14(2) Uredbe te njezine ciljeve i strukturu, presuda zbog ogluhe donesena u slučaju nemogućnosti utvrđenja tuženikova prebivališta ne može se potvrditi kao EON.“52 O stajalištu SEU-a o

45 Vid. recital (12) Uredbe.

46 CURIA, judgment of 28 February 2018, C-289/17, Collect Inkasso OÜ, ITM Inkasso OÜ, Bigbank AS v. Rain Aint, Lauri Palm, Raiko Oikimus, Egle Noor, Artjom Konjarov, para. 36, Zulfikarpašić, para. 48.

47 Recital (10) Uredbe.

48 Lazić, V., 2017, str. 38-39.

49 Recital (13) Uredbe.

50 Recital (11) Uredbe.

51 CURIA, judgment of 15 March 2012, C-292/10, G v. Cornelius de Visser, para. 64.

52 CURIA, judgment of 27 June 2019, C-518/18, RD v. SC, para. 26. 
dostavi prema odredbi članka 14(1)(a) Uredbe, tj. o osobnoj dostavi na adresi dužnika osobama koje s dužnikom žive u istome kućanstvu ili su tamo zaposlene bilo je riječi supra (predmet C-354/15).

Odredba članka 15. Uredbe omogućuju dostavu dužnikovom zastupniku. ${ }^{53}$ Pojašnjavajući pojam 'dužnikov zastupnik' SEU kaže da se „privremeni zastupnik poput onoga postavljenog na temelju nacionalnog propisa u glavnom postupku ne može izjednačiti s dužnikovim zastupnikom iz članka 15. Uredbe [...] te da recital (16) Uredbe mogućnost dostave zastupniku dužnika ne vidi u odnosu na privremenog zastupnika, već samo na zastupnika postavljenog u slučaju kada je dužnik zbog zakonitih razloga objektivno spriječen sam se zastupati pred sudom, odnosno kada je dužnik dobrovoljno odredio da ga se zastupa" $(R D, \S 28)$.

Obvezan sadržaj pismena kojima se pokreće postupak i drugih odgovarajućih pismena, tj. koje se 'informacije' moraju priopćiti dužniku predviđaju čl. 16. i 17. Uredbe ${ }^{54} \mathrm{U}$ prvom se navodi koje sve podatke pismena trebaju sadržavati da bi se osiguralo da dužnik dobije „pravodobnu obavijest o tražbini“. U drugom, „pravodobne obavijesti o postupovnim koracima potrebnim za osporavanje tražbine". Smjernice za razumijevanje članka 17. Uredbe iznesene su u predmetu Collect Inkasso gdje ga se dovelo u vezu s člankom 18. Uredbe. Do problema je došlo zbog toga što su u sudskim odlukama bile izostavljene obavijesti tužitelju „o adresi suda kojem je trebalo odgovoriti, odnosno pred kojim se dužnik morao pojaviti” $(\$ 29)$. Pred sudom koji je postavio prethodno pitanje vođeno je više postupaka za potvrđivanje platnih naloga. Svima je zajedničko bilo da „podnescima kojim se pokretao sudski postupak i rješenja donesena u postupku izdavanja platnog naloga, iako dostavljena dužnicima, nisu sadržavali podatke o adresi suda nadležnog za vođenje postupaka ili ispitivanje eventualnog pravnog lijeka protiv rješenja” (\$30). Najprije je naglašeno da „članak 17(a) Uredbe zahtijeva da se određeni elementi, uključujući naziv i adresu ustanove kojoj se treba odgovoriti ili, ako je primjenjivo, ustanove pred kojom se mora pojaviti, jasno navedu u podnesku ili uz podnesak kojim se pokreće sudski postupak, u ekvivalentnom pismenu ili u bilo kakvom pozivu na ročište" ( $\$ 33)$. Zatim je protumačeno da za (eventualno) otklanjanje nepoštivanja minimalnih standarda „članak 18(1) (b) Uredbe zahtijeva da dužnik ima mogućnost ispitivanja sudske odluke o tražbini podnošenjem zahtjeva za njezino puno preispitivanje i da u njoj ili uz nju bude pravodobno obaviješten o postupovnim zahtjevima za takvo ispitivanje, uključujući naziv i adresu ustanove kod koje se ispitivanje pokreće" ( $\$ 34)$. Zaključak je glasio da „iz teksta članka 17 (a) i članka 18(1) (b) Uredbe [...] proizlazi da je navođenje dužniku adrese odnosne ustanove obvezno" (\$35). U članku 18. Uredbe predviđeni su, naime, mehanizmi koji omogućuju 'saniranje' neusklađenosti $s$ minimalnim standardima. ${ }^{55}$ Točnije, da se, pod određenim pretpostavkama, čak i kada postupak u državi članici podrijetla ne ispunjava postupovne pretpostavke iz čl. 13. do 17. Uredbe neusklađenost otkloni, a sama sudska odluka potvrdi

53 Recital (16) Uredbe.

54 Mizaras, V., Brazdeikis, A., 2012, p. 452, Lazić, V., 2017, str. 38-39.

55 Mizaras, V., Brazdeikis, A. upozoravaju na njegovu utemeljenost na člancima 34(2) Brussels I, odnosno članku 45(1)(b) Brussels I recast. Ibid., p. 465. 
kao EON. No, kako se supra vidjelo, ovo nije moguće kada je „sudska odluka donesena bez obavještavanja dužnika o adresi suda kojem treba odgovoriti, pred kojim se mora pojaviti ili, ako je primjenjivo, pred kojim se može pokrenuti ispitivanje te odluke [...] pa takva odluka ne može biti potvrđena kao EON" (Collect Inkasso, \$39).

Članak 19. Uredbe uređuje pretpostavke 'posebnog preispitivanja ${ }^{56}$ pa kaže da „nastavno na članke 13. do 18. Uredbe, sudska odluka, ipak, može biti potvrđena kao EON ima li dužnik u skladu s pravom države članice podrijetla mogućnost zatražiti njezino preispitivanje uz uvjete koji su u njemu (članku 19. Uredbe) sadržani.“ Države članice nemaju, međutim, dužnost „takav postupak uvesti u svoje nacionalno pravo" (Imtech Marine Belgium, $₫ 27) .{ }^{57}$ Osim toga, odgovarajući na pitanje „čime članak 19(1) Uredbe uvjetuje da se neka presuda zbog ogluhe potvrdi kao EON” (Imtech Marine Belgium, \$ 32), SEU u citiranom predmetu ukratko odgovara: „Članak 19(1) Uredbe treba tumačiti na način da, kako bi se presuda zbog ogluhe potvrdila kao EON, sudac kojemu je podnesen takav prijedlog treba osigurati da njegovo nacionalno pravo uistinu i bez iznimke u dva slučaja predviđena tom odredbom dopušta potpuno preispitivanje takve odluke, i s činjenične i s pravne strane, te da dopušta produljenje rokova za podnošenje žalbe protiv odluke koja se odnosi na nespornu tražbinu, ne samo u slučaju više sile već i kada su druge izvanredne okolnosti, neovisno o dužnikovoj volji, spriječile potonjeg da osporava predmetnu tražbinu” ( $\$ 42)$.

\subsubsection{Posebne pretpostavke za potvrdu javnih isprava kao EON-a}

Pretpostavke koje se traže da bi javna isprava bila potvrđena kao EON sadržavaju čl. 25, 4(1) i 3(1)(d) Uredbe. Definiciju 'javne isprave' predviđa članak 4(3)(a) i (b) Uredbe. ${ }^{58}$ U predmetu Zulfikarpašić objašnjen je zahtjev o 'nespornosti' tražbine iz javne isprave u smisli članka 3(d) Uredbe i u tom pravcu kazano da se „u članku 3. Uredbe [...] definiraju uvjeti pod kojima se tražbina smatra nespornom, pri čemu postoji razlika između slučajeva iz stavka 1. točaka (a) do (c) tog članka koji se odnose na tražbine utvrđene u okviru sudskog postupka i slučajeva iz točke (d) tog stavka koji se tiču tražbina koje je dužnik izričito prihvatio u javnoj ispravi“ (\$ 52). SEU je apostrofirao da „pravilna primjena tog članka ne dopušta da se nepostojanje dužnikova prigovora izjednačava s izričitim prihvaćanjem tražbine u smislu članka 3(1) (d) Uredbe, jer ono mora biti navedeno u javnoj ispravi za koju se izdaje potvrda", pa zbog toga i zaključio da „rješenje o ovrsi koje u Hrvatskoj donosi javni bilježnik na temelju vjerodostojne isprave, a protiv kojeg nije bilo prigovora, ne može potvrditi kao EON-u jer se ono ne odnosi na nespornu tražbinu u smislu članka 3(1) Uredbe" (\$\$ 58-59).

56 Lazić, V., 2017, str. 38-39.

57 Recital (19) Uredbe.

58 Vid. za javnu ispravu, judgment of 17 June 1999, Case C-260/97, Unibank A/S v. Flemming G. Christensen, paras. 15, 17, 18, cit. prema: Hess, B., 2008, p. 279. 


\section{OVRHA NA TEMELJU ISPRAVE POTVRĐENE KAO EON-A}

Ovrhu sudske odluke potvrđene kao EON-a uređuju čl. 20. do 23. Uredbe. Temeljno pravilo je da se, sukladno članku 20(1) Uredbe, izvršenje u drugoj državi članici provodi primjenom njezinih nacionalnih pravila (lex loci executionis), ${ }^{59}$ pa takvo rješenje predviđa i hrvatsko ovršno pravo. Pažnju plijeni trećim stavkom članka 20. Uredbe stipulirana zabrana cautio judicatum solvi koju, kako naglašava doktrina, treba promatrati zajedno s pravilima iz članka 23. Uredbe o odgodi, odnosno ograničenju ovrhe. ${ }^{60}$ Riječ je o ideji europskog zakonodavca da zaštiti dužnika u onim slučajevima kada je ovršni naslov, potvrđen kao EON, podvrgnut provjeri u državi članici podrijetla, a nije odgođena ovrha. ${ }^{61}$ Do odgode ili ograničavanja ovrhe doći će, prema članku 23(1) Uredbe, , ako je dužnik podnio prijedlog za ispitivanje sudske odluke potvrđene kao EON uključujući i prijedlog u smislu članka 19. Uredbe ili zatražio ispravak ili povlačenje potvrde EON-a u skladu s člankom 10. Uredbe." Korisno je znati da se u teoriji smatra da, po uzoru na njemačku pravnu doktrinu, u moguće slučajeve 'ožalbljenja' treba uključiti i one kada je podnesen zahtjev Europskom sudu za ljudska prava. ${ }^{62}$

\section{ZAKLJUČAK}

Uredba je jedan od instrumenata prava Unije kojim se omogućuje slobodan protok sudskih odluka, sudskih nagodba i javnih isprava uz snažno oživotvorenje načela Unije. Ona se nalazi u neraskidivoj vezi s drugim instrumentima prava Unije, posebice uredbama iz tzv. briselskog režima. Stoga, sukladnost nacionalnih pravila koja osobito dolaze do izražaja kod provjere postupovnih standarda i ovrhe na temelju potvrđenih naslova treba ocjenjivati poštujući te odnose, a pogotovo i u Uredbi naglašenu posvećenost Unije zaštićenim pravima i proklamiranim načelima. U literaturi se višestruko upozorava na potrebu pridržavanja načela na kojima počiva sustav pravosudne suradnje u građanskim stvarima. Primarno, načela uzajamnog priznavanja sudskih odluka ${ }^{63}$ koje je označeno 'uzglavnim kamenom' i čija je primjena omogućila ukidanje delibacijskog postupka te načelo uzajamnog povjerenja ${ }^{64}$ koje pretpostavlja 'savjesnost' država članica u ispunjenju pretpostavki za potvrdu i ovrhu EON-a, odnosno na temelju EON-a ${ }^{65}$ što, u konačnici, omogućuju veći stupanj zaštite dužnika (potrošača) kojeg SEU ostvaruje svojom praksom.

59 V. Kačevska, I., Rudevska, B., 2012, p. 120.

60 Ibid., p. 121.

61 Ibid., p. 126.

62 Ibid., pp. 126-127.

63 Marcos, M., 2013, p. 95.

64 Medić, I., 2017, Priznanje i ovrha na području EU, Zbornik radova Pravnog fakulteta u Splitu, Vol. 54, br. 1, str. 283-300.

65 Garašić, J., Uvod u europsko građansko procesno pravo, Garašić, J. (ur.) 2013, Europsko gradansko procesno pravo: izabrane teme, Zagreb, Narodne novine, str. 19. 


\section{LITERATURA}

1. Babić, D., Jessel Holst, C., 2011, Međunarodno privatno pravo, Zagreb, Narodne novine.

2. Babić, D., Vremenske granice primjene uredaba 44/2001 i 1215/2012 u Hrvatskoj, u: Garašić, J. (ur.) 2013, Europsko građansko procesno pravo: izabrane teme, Zagreb, Narodne novine.

3. Garašić, J., Uvod u europsko građansko procesno pravo, u: Garašić, J. (ur.) 2013, Europsko građansko procesno pravo: izabrane teme, Zagreb, Narodne novine.

4. Hess, B. et al., 2008, The Brussels I Regulation 44/2001, The Heidelberg Report on the Application of Regulation Brussels I in 25 Member States (Study JLS/C4/2005/03), Munich: Verlag C.H. Beck, (http://ec.europa.eu/civiljustice/news/docs/study_application_brussels_1_en.pdf, 3. 5.2019).

5. Kramberger Škerl, J., The Application "Ratione Temporis" of the Brussels I Regulation (Recast), u: Duić, D., Petrašević, T., (ur.) 2017, Procedural Aspects of EU Law, Osijek, Josip Juraj Strossmayer University of Osijek, Faculty of Law Osijek, (https:// hrcak.srce.hr/ojs/index.php/eclic/article/view/6536, 23. 7. 2020).

6. Kunštek, E., 2007, Pretpostavke za izdavanje potvrde o europskom ovršnom nalogu, Zbornik Pravnog fakulteta u Rijeci, vol. 28, br. 1, str. 441-492.

7. Marcos, M., 2013, European Union Civil Justice and European Union Criminal Justice, Waikato Law Review, vol. 21, pp. 95-124, (http://www.austlii.edu.au/au/journals/ WkoLawRw/2013/8.pdf, 23. 7. 2020).

8. Medić, I., 2017, Priznanje i ovrha na području EU, Zbornik radova Pravnog fakulteta u Splitu, vol. 54, br. 1, str. 283-300.

9. Mihelčić, G., 2019, O dostavi prema minimalnim standardima za potvrdu sudske odluke kao europskog ovršnog naslova, Pravo i porezi, 12, str. 65-70.

10. Poretti, P., Pravo EU u građanskom procesnom pravu, u: Petrašević, T., Vuletić, I. (ur.) 2016, Procesno-pravni aspekti prava EU, Osijek, Pravni fakultet Sveučilišta Josipa Jurja Strossmayera u Osijeku, str. 91-124.

\section{PROPISI}

1. Commission Regulation (EC) No 1869/2005 of 16 November 2005 replacing the Annexes to Regulation (EC) No 805/2004 of the European Parliament and of the Council creating a European Enforcement Order for uncontested claims, OJ L 300, 17. 11. 2005, pp. 6-8.

2. Corrigendum to Regulation (EC) No 805/2004 of the European Parliament and of the Council of 21 April 2004 creating a European Enforcement Order for uncontested claims, OJ L 97, 15. 4. 2005, p. 64.

3. Council regulation (EC) No 1348/2000 of 29 May 2000 on the service in the Member States of judicial and extrajudicial documents in civil or commercial matters, OJ L 160, 30. 6. 2000, pp. 37-52.

4. Council Regulation (EC) No 4/2009 of 18 December 2008 on jurisdiction, applicable law, recognition and enforcement of decisions and cooperation in matters relating to maintenance obligations, OJ L 7, 10. 1. 2009, pp. 1-79.

5. Regulation (EC) No 1103/2008 of the European Parliament and of the Council of 22 October 2008 adapting a number of instruments subject to the procedure laid down 
in Article 251 of the Treaty to Council Decision 1999/468/EC, with regard to the regulatory procedure with scrutiny - Adaptation to the regulatory procedure with scrutiny - Part Three, OJ L 304, 14. 11. 2008, pp. 80-84.

6. Regulation (EC) No 1393/2007 of the European Parliament and of the Council of 13 November 2007 on the service in the Member States of judicial and extrajudicial documents in civil or commercial matters (service of documents), and repealing Council Regulation (EC) No 1348/2000, OJ L 324, 10. 12. 2007, pp. 79-120.

7. Regulation (EC) No 805/2004 of the European Parliament and of the Council of 21 April 2004 creating a European Enforcement Order for uncontested claims, OJ L 143, 30. 4. 2004, pp. 15-39.

8. Regulation (EC) No 44/2001 of 22 December 2000 on jurisdiction and the recognition and enforcement of judgments in civil and commercial matters, OJ L 12, 16. 1. 2001, pp. 1-23.

9. Regulation (EU) No 1215/2012 of the European Parliament and of the Council of 12 December 2012 on jurisdiction and the recognition and enforcement of judgments in civil and commercial matters (recast), OJ L 351, 20. 12. 2012, pp. 1-32.

\section{SUDSKA PRAKSA}

1. CURIA, judgment of 15 March 2012, C-292/10, G v. Cornelius de Visser.

2. CURIA, judgment of 2 March 2017, C-354/15, Andrew Marcus Henderson v. Novo Banco SA.

3. CURIA, judgment of 27 June 2019, C-518/18, RD v. SC.

4. CURIA, judgment of 14 December 2017, Case C-66/17, Grzegorz Chudaś, Irena Chudaś v. DA Deutsche Allgemeine Versicherung Aktiengesellschaft.

5. CURIA, judgment of 15 November 2018, C-308/17, Hellenische Republik v. Leo Kuhn.

6. CURIA, judgment of 16 June 2016, C-511/14, Pebros Servizi v. Aston Martin Lagonda Ltd.

7. CURIA, judgment of 16 November 2016, C-417/15, Wolfgang Schmidt v. Christiane Schmidt.

8. CURIA, judgment of 17 June 1999, Case C-260/97, Unibank A/S v. Flemming G. Christensen.

9. CURIA, judgment of 17 December 2015, C-300/14, Imtech Marine Belgium NVv. Radio Hellenic SA.

10. CURIA, judgment of 21 June 2012, C-514/10, Wolf Naturprodukte GmbH v. SEWAR spol. s r. o.

11. CURIA, judgment of 22 October 2015, C-523/14, Aannemingsbedrijf Aertssen NV, Aertssen Terrassements SA v. VSB Machineverhuur BV, Van Sommeren Bestrating BV, Jos van Sommeren.

12. CURIA, judgment of 23 October 2014, C-302/13, flyLAL-Lithuanian Airlines v. Starptautiskā lidosta Rìga VAS, Air Baltic Corporation AS.

13. CURIA, judgment of 28 February 2018, C-289/17, Collect Inkasso OÜ, ITM Inkasso OÜ, Bigbank AS v. Rain Aint, Lauri Palm, Raiko Oikimus, Egle Noor, Artjom Konjarov.

14. CURIA, judgment of 28 February 2019, C-579/17, BUAK Bauarbeiter-Urlaubs-u. Abfertigungskasse v. Gradbeništvo Korana d.o.o., para. 46, v. i Pula Parking, para. 33.

15. CURIA, judgment of 5 December 2013, C-508/12, Walter Vapenik v. Josef Thurner. 
16. CURIA, judgment of 7 May 2020, C-267/19 i C-323/19, PARKING d.o.o. and Interplastics s.r.o. v. SAWAL d.o.o. and Letifico d.o.o.

17. CURIA, judgment of 9 March 2017, C-484/15, Ibrica Zulfikarpašić v. Slaven Gajer, para. 43.

18. CURIA, judgment of 9 March 2017, C-551/15, Pula Parking d.o.o. v. Sven Klaus Tederahn.

19. CURIA, order of 6 November 2019, C-234/19, EOS Matrix d.o.o. v. Entazis d.o.o.

20. Opinion of Advocate General Bot delivered on 8 September 2016, Ibrica Zulfikarpašić v. Slaven Gajer.

21. Opinion of Advocate General Villalón delivered on 8 September 2015, Imtech Marine Belgium NV v. Radio Hellenic SA.

\section{IZVORI SA INTERNETA}

1. Lazić, V., 2017, Regulations Brussels Ibis and Regulation creating a European Enforcement Order, (www.jacz.cz/images/stories/PROJECT_TRAINING_LEGAL_LANGUAGES/4_text_AJ/Text4.pdf, 23. 7. 2020).

2. Galič, A., 2016, Civil judicial cooperation, u: Handbook, English for Judicial Cooperation in Civil Matters, EJTN, (http://www.ejtn.eu/Documents/Resources/Handbook_Manuel_Linguistics_Civil.pdf, 23. 7.2020).

3. Kačevska, I., Rudevska, B., Chapter 1: Latvia, 2012, u: Kačevska, I. (ur.) et al., Practical Application of European Union Regulations Relating to European Union Level Procedure in Civil Cases: the Experience in Baltic States, (https://www.just.ee, 3. 5. 2019).

4. Kačevska, I., Rudevska, B., General insight into the application of Regulations, 2012, u: Kačevska, I. (ur.) et al., Practical Application of European Union Regulations Relating to European Union Level Procedure in Civil Cases: the Experience in Baltic States, (https://www.just.ee, 3. 5. 2019).

5. Kramer, X., et al., The application of Brussels I (Recast) in the legal practice of EU Member States, Synthesis Report, (https://www.asser.nl/media/5018/m-5797-ec-justice-the-application-of-brussels-1-09-outputs-synthesis-report.pdf, 23. 7. 2020).

6. Mizaras, V., Brazdeikis, A., Chapter 2: Lithuania, 2012, u: Kačevska, I. (ur.) et al., Practical Application of European Union Regulations Relating to European Union Level Procedure in Civil Cases: the Experience in Baltic States, (https://www.just.ee, 3. 5. 2019).

7. Sessa, Đ., Katić, D., 2017, Dostava izvan Hrvatske, Zagreb, Pravosudna akademija.

8. Tampere European Council 15-16 October 1999. Presidency conclusions, (http:// www.europarl.europa.eu/summits/tam_en.htm, 23. 7. 2020).

9. Torga, M., Chapter 3: Estonia, 2012, u: Kačevska, I. (ur.) et al., Practical Application of European Union Regulations Relating to European Union Level Procedure in Civil Cases: the Experience in Baltic States, (https://www.just.ee, 3. 5. 2019). 


\title{
CASE LAW OF THE COURT OF JUSTICE OF THE EUROPEAN UNION ON THE EUROPEAN ENFORCEMENT ORDER - SELECTED ISSUES
}

\author{
Gabrijela Mihelčić
}

\section{SUMMARY}

The author discusses the case law of the Court of Justice of the European Union on the European Enforcement Order as an instrument for the collection of uncontested pecuniary claims. The analysis shows the importance of respecting principles of mutual trust and mutual recognition for the confirmation of court decisions, court settlements and public instruments as EEO, as well as for enforcement based on those instruments. Indirectly, an enhanced consumer protection is provided. More precisely, this research confirms that the Court, following the principles in question, restrictively interprets the assumptions set out in Regulation (EC) No 1/2003. 805/2004 that allow the free flow of court decisions, court settlements and public instruments in all Member States bearing in mind the 'welfare' of debtors in general.

Key words: principle of mutual trust, principle of mutual recognition, Regulation (EC) No. 805/2004, European Enforcement Order. 